\title{
Synthesis, Structure and Bonding of a Digold Complex with Bridging \\ Triphenylstannyl Ligands.
}

\author{
Richard D. Adams*, Yuen Onn Wong and Qiang Zhang \\ Department of Chemistry and Biochemistry \\ University of South Carolina
}

Columbia, SC, 29208

E-mail: $\underline{\text { Adamsrd@mailbox.sc.edu }}$

*Dedicated to Professor Hubert Schmidbaur on the occasion of his $80^{\text {th }}$ birthday.

\section{Introduction}

Interest in the organometallic chemistry of gold has grown rapidly in recent years following the discoveries that gold nanoparticles supported on metal oxides exhibit surprisingly high activity for the catalytic oxidation of $\mathrm{CO}$ and selected hydrocarbons [1]. Studies have also shown bimetallic catalysts containing gold exhibit even better activity for oxidation catalysis [2]. Tin is well known for its ability to serve as a modifier of heterogeneous metal catalysts [3]. A recent study has shown that $\mathrm{Au} / \mathrm{SnO}_{2}$ catalyst exhibits oxidation activity comparable to $\mathrm{Au} / \mathrm{TiO}_{2}$, one of the most active catalytic gold oxidation systems [4]. Gold complexes can also perform novel forms of dual catalysis homogeneously when combined with other metals, most notably with palladium [5].

There are very few examples of organometallic gold-tin complexes in the literature. Examples with terminally-coordinated tin ligands include $\mathrm{Au}\left(\mathrm{PMe}_{2} \mathrm{Ph}\right)_{2}\left(\mathrm{SnCl}_{3}\right), \mathbf{1}, \mathrm{Au}-\mathrm{Sn}=$ 2.881(1) $\AA$ [6] and $\mathrm{Au}\left(\mathrm{PPh}_{3}\right)\left[\mathrm{Sn}\left\{\mathrm{N}(p \text {-tol }) \mathrm{SiMe}_{2}\right\}_{3} \mathrm{SiMe}\right], 2$, [7], see Scheme 1. 


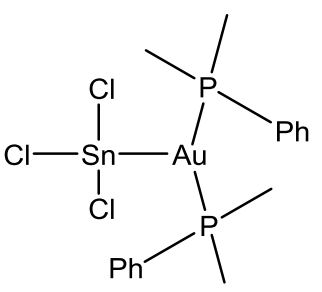

1

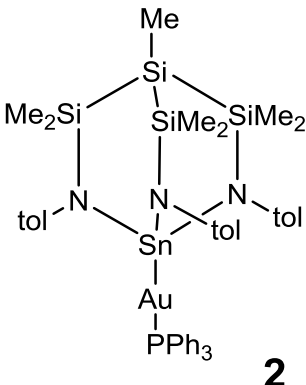

2

Scheme 1. Line structures for compounds $\mathbf{1}$ and $\mathbf{2}$.

Compounds $\left[\mathrm{Au}_{4}\left(\mathrm{PPh}_{3}\right)_{4}\left(\mu-\mathrm{SnCl}_{3}\right)_{2}\right], 3$ [8] and $\mathrm{Au}_{4}\left(\mathrm{PPh}_{3}\right)_{4}\left[\mu-\mathrm{SnCB}_{10} \mathrm{H}_{11}\right]_{2}, 4$ [9] and the dianion compound $\left[\mathrm{Bu}_{3} \mathrm{NH}\right]_{2}\left[\left(\mathrm{PPh}_{3}\right) \mathrm{Au}\left(\mu-\mathrm{SnB}_{11} \mathrm{H}_{11}\right)\right]_{2}, 5[10]$ have bridging Sn ligands, Scheme 2.

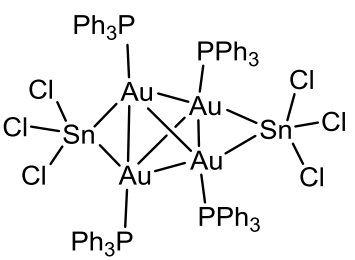

3

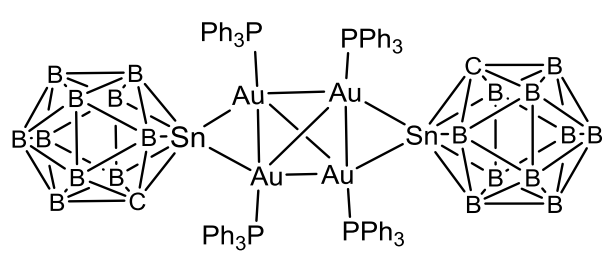

4

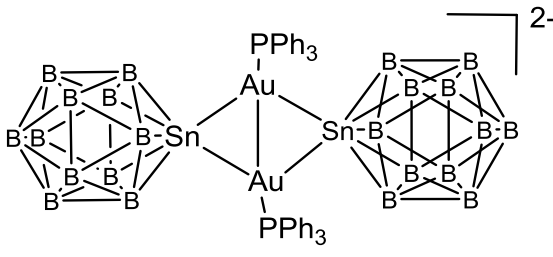

5

Scheme 2. Structures of $\mathbf{3}, \mathbf{4}$ and the anion of 5.

We have recently found that aryl containing gold phosphine complexes, $\mathrm{Au}\left(\mathrm{PPh}_{3}\right) \mathrm{Ar}, \mathrm{Ar}$ $=\mathrm{Ph}, \mathrm{Np}, \mathrm{Py}$, react with certain dirhenium [11] and triosmium [12] carbonyl complexes to yield electronically unsaturated complexes containing bridging aryl ligands. In the present work, we have investigated the reaction of $\mathrm{Au}\left(\mathrm{PPh}_{3}\right) \mathrm{Ph}$ with $\mathrm{HSnPh}_{3}$. The principal product is a new digold-ditin complex $\left[\mathrm{Au}\left(\mathrm{PPh}_{3}\right)\left(\mu-\mathrm{SnPh}_{3}\right)\right]_{2}, 6$ that contains two bridging $\mathrm{SnPh}_{3}$ ligands. The results of our studies of the synthesis, structural characterization and bonding in this compound are described in this report.

\section{Experimental Details}


General Data. Reagent grade solvents were dried by the standard procedures and were freshly distilled prior to use. Infrared spectra were recorded on a Thermo Nicolet Avatar 360 FT-IR spectrophotometer. ${ }^{1} \mathrm{H}$ NMR and ${ }^{31} \mathrm{P}\left\{{ }^{1} \mathrm{H}\right\}$ NMR were recorded on a Varian Mercury 400 spectrometer operating at 400.1 and $161.9 \mathrm{MHz}$ respectively. ${ }^{31} \mathrm{P}\left\{{ }^{1} \mathrm{H}\right\}$ NMR spectra were referenced externally by using $85 \%$ ortho $-\mathrm{H}_{3} \mathrm{PO}_{4}$. Solid state ${ }^{119} \mathrm{Sn}$ cross-polarization magic angle spinning (CP-MAS) spectra were collected on a Bruker Avance III-HD $500 \mathrm{MHz}$ spectrometer fitted with a $1.9 \mathrm{~mm}$ MAS probe and were referenced against $\mathrm{SnPh}_{4}$. The spectra was collected at ambient temperature with a sample rotation rate of $20 \mathrm{KHz}$. $\mathrm{HSnPh}_{3}$ was obtained from SIGMA-ALDRICH and was used without further purification. $\mathrm{Au}\left(\mathrm{PPh}_{3}\right) \mathrm{Ph}$ was prepared according to the previously reported procedure [13]. Product separations were performed by TLC in air on Analtech $0.25 \mathrm{~mm}$ alumina $60 \AA F_{254}$ glass plates.

\section{Reaction of $\mathrm{HSnPh}_{3}$ with $\mathrm{Au}\left(\mathrm{PPh}_{3}\right) \mathrm{Ph}$}

$30.0 \mathrm{mg}(0.026 \mathrm{mmol})$ of $\mathrm{Au}\left(\mathrm{PPh}_{3}\right) \mathrm{Ph}$ was added to $18.6 \mathrm{mg}(0.052 \mathrm{mmol})$ of $\mathrm{HSnPh}_{3}$ dissolved in $10 \mathrm{~mL}$ of benzene. The solution was allowed to stir for $7 \mathrm{~h}$ at room temperature. A red-orange solution was formed and the solvent was then removed in vacuo. The residue was extracted in methylene chloride and separated by TLC by using hexane solvent to elute a yellow band of $\left[\mathrm{Au}\left(\mathrm{PPh}_{3}\right)\left(\mu-\mathrm{SnPh}_{3}\right)\right]_{2}, 618.8 \mathrm{mg}(52 \%)$ and $\mathrm{Sn}_{2} \mathrm{Ph}_{6}, 8.6 \mathrm{mg}(46 \%)$. The orange crystals of pure

6 can be physically separated from the colorless crystals of the $\mathrm{Sn}_{2} \mathrm{Ph}_{6}$. Spectral data for 6 : ${ }^{1} \mathrm{H}$ $\operatorname{NMR}\left(\mathrm{CD}_{2} \mathrm{Cl}_{2}\right.$, in ppm) $\delta=7.50(\mathrm{~m}, 15 \mathrm{H}), 7.35(\mathrm{~m}, 15 \mathrm{H}) .{ }^{119} \mathrm{Sn}$ CP-MAS (in ppm) $\delta=121.01$ (s). ${ }^{31} \mathrm{P}$ NMR $\left(\mathrm{CD}_{2} \mathrm{Cl}_{2}\right.$, in ppm) $\delta=43.33(\mathrm{~s})$. Anal. Calcd for 1: C, 53.42; H, 3.73. Found: $\mathrm{C}$, 56.65; H, 4.10. Samples of 6 inevitably contain small amounts of $\mathrm{Sn}_{2}\left(\mathrm{C}_{6} \mathrm{H}_{5}\right)_{6}$ formed by its decomposition. This could explain the high measurements for $\mathrm{C}$ and $\mathrm{H}$. 


\section{Crystallographic Analysis}

Orange single crystals of $\mathbf{6}$ crystallize together with colorless crystals of $\mathrm{Sn}_{2} \mathrm{Ph}_{6}$ (a decomposition product) upon slow evaporation of solvent from a solution in methylene chloride at $15^{\circ} \mathrm{C}$. An orange crystal of $\mathbf{6}$ was glued onto the end of a thin glass fiber. X-ray intensity data were measured by using a Bruker SMART APEX CCD-based diffractometer by using Mo K $\alpha$ radiation $(\lambda=0.71073 \AA)$. The raw data frames were integrated with the SAINT+ program by using a narrow-frame integration algorithm [14]. Correction for Lorentz and polarization effects were also applied by using SAINT+. An empirical absorption correction based on the multiple measurement of equivalent reflections was applied by using the program SADABS. The structure was solved by a combination of direct methods and difference Fourier syntheses, and refined by full-matrix least-squares on $\mathrm{F}^{2}$, using the SHELXTL software package [15]. All nonhydrogen atoms were refined with anisotropic displacement parameters. The hydrogen atoms were placed in geometrically idealized positions and included as standard riding atoms during the final cycles of least-squares refinements. Compound $\mathbf{6}$ crystallized in the orthorhombic crystal system with one equivalent of $\mathrm{CH}_{2} \mathrm{Cl}_{2}$ cocrystallized from the crystallization solvent. The space group $\mathrm{P} 2{ }_{1} 2{ }_{1} 2$ was uniquely identified by the pattern of systematic absences observed in the data. Crystal data, data collection parameters, and results of the analyses are listed in Table 1.

\section{Computational Details.}

Density functional theory (DFT) calculations were performed with the Amsterdam Density Functional (ADF) suite of programs [16] by using the PBEsol functional [17] with valence quadruple- $\zeta+4$ polarization function, relativistically-optimized (QZ4P) basis sets for the gold, tin, phosphorus, carbon and hydrogen atoms with frozen cores. The molecular orbitals for compound 6 and their energies were determined by geometry-optimized calculations with scalar 
relativistic corrections that were initiated by using the atom positional parameters for the molecule as determined from the crystal structure analysis. The geometry-optimized coordinates of $\mathbf{6}$ are given in Table S1.

\section{Results and Discussion}

The reaction of $\mathrm{Au}\left(\mathrm{PPh}_{3}\right) \mathrm{Ph}$ with $\mathrm{HSnPh}_{3}$ yielded the new digold-ditin complex, $\left[\mathrm{Au}\left(\mathrm{PPh}_{3}\right)\left(\mu-\mathrm{SnPh}_{3}\right)\right]_{2}, 6$ in $52 \%$ yield. $\mathrm{Sn}_{2} \mathrm{Ph}_{6}$ was a major coproduct that was obtained in $46 \%$ yield. $\mathrm{Sn}_{2} \mathrm{Ph}_{6}$ was subsequently found to be formed by the degradation of $\mathbf{6}$. The formation of benzene was observed when the reaction was performed in an NMR tube in $\mathrm{CD}_{2} \mathrm{Cl}_{2}$ solvent. Compound 6 was characterized structurally by a single-crystal X-ray diffraction analysis. An ORTEP diagram of its molecular structure is shown in Figure 1. The molecule contains two $\mathrm{Au}\left(\mathrm{PPh}_{3}\right)$ groups that are joined by a strong $\mathrm{Au}-\mathrm{Au}$ bond that is bridged by two $\mathrm{SnPh}_{3}$ groups. In the solid state the molecule lies on a crystallographic two-fold rotation axis that lies perpendicular to the $\mathrm{Au}-\mathrm{Au}$ bond. The $\mathrm{Au}-\mathrm{Au}$ distance in 6 is short, 2.5590(5) $\AA$, and is shorter than the $\mathrm{Au}-\mathrm{Au}$ bond distance found in the $\mathrm{SnB}_{11} \mathrm{H}_{11}$-bridged digold dianion of compound 5, $\mathrm{Au}-\mathrm{Au}=2.625(1) \AA$ (Scheme 2) [10]. The $\mathrm{P}-\mathrm{Au}-\mathrm{Au}^{\mathrm{i}}$ angle in $\mathbf{6}, 170.74(5)^{\circ}$, is almost linear and is similar to that in $\mathbf{5}, 178.78(4)^{\circ}$. Mingos described the structure of digold molecule $\mathrm{Ph}_{3} \mathrm{AuAuPPh} 7$ which has no bridging ligands [18]; the $\mathrm{Au}-\mathrm{Au}$ distance given for 7 is $2.76 \AA$. Although the identity of 7 has recently been questioned [19], Bertrand recently reported a related unbridged digold-dicarbene complex (CAAC)AuAu(CAAC), 8 CAAC $=$ cyclic(alkyl)(amino)carbene [20] that contains a very short $\mathrm{Au}-\mathrm{Au}$ bond, 2.5520(6) $\AA$ having nearly linear $\mathrm{C}-\mathrm{Au}-\mathrm{Au}$ angles, $173.8(2)^{\circ}$ and $171.3(3)^{\circ}$. The shortest reported $\mathrm{Au}-\mathrm{Au}$ bond distances are for the complexes $\left[\mathrm{Au}_{2}(\mathrm{hpp})_{2} \mathrm{Cl}_{2}\right], \mathrm{Au}-\mathrm{Au}=2.4752(9) \AA$, $\left[\left(\mathrm{PhCO}_{2}\right)_{6} \mathrm{Au}_{4}(\mathrm{hpp})_{2} \mathrm{Ag}_{2}\right], \mathrm{Au}-\mathrm{Au}=2.4473(19) \AA$, hpp = 3,4,6,7,8,9-hexahydro-pyrimido[1,2- 
a]pyrimidinate [21]. Compound 6 contains two independent $\mathrm{Au}-\mathrm{Sn}$ distances, Au1 $-\mathrm{Sn} 1=$ 2.8207(16) $\AA$ and Au1-Sn $1^{\mathrm{i}}=2.9038(6) \AA$ that are statistically different in length. This is probably due to the rotational conformation of the $\mathrm{SnPh}_{3}$ group. These distances are much longer than that to the terminally coordinated tin ligand in compound $2, \mathrm{Au}-\mathrm{Sn}=2.5651(13) \AA$ [7], but are similar to the bridging Au-Sn distances reported for the compounds 3, 2.8150(7) $\AA$ and 2.9725(8) $\AA[8]$; 4, 2.891(1) $\AA, 2.727(1) \AA, 2.936(1) \AA$, and 2.757(1) [9] and the dianion 5, 2.737(1) $\AA$ and 2.761(1) $\AA$ [10] (see Scheme 2). The Au - Sn - Au angle in $6\left(53.08^{\circ}\right)$ is slightly smaller than the $\mathrm{Au}-\mathrm{Sn}-\mathrm{Au}$ angle $\left(57.03^{\circ}\right)$ in $\mathbf{5}$ as a result of the shorter $\mathrm{Au}-\mathrm{Au}$ distance in $\mathbf{6}$. The $\mathrm{Au}_{2} \mathrm{Sn}_{2}$ ring is almost planar; the dihedral angle between the two $\mathrm{Au}_{2} \mathrm{Sn}$ triangles is $163.57(2)^{\circ}$. It is unlikely that there is any significant direct $\mathrm{Sn}-\mathrm{Sn}$ bonding interaction, because the $\mathrm{Sn}{ }^{*} \mathrm{Sn}$ distance is very long at 5.069(1) $\AA$. Compound $\mathbf{6}$ does not exhibit a ${ }^{119} \mathrm{Sn}$ NMR signal in solutions; however, a ${ }^{119} \mathrm{Sn}$ CP-MAS spectrum of $\mathbf{6}$ does show a singlet at $\delta=121.01$ in the solid state. This is consistent with the solid state structure having equivalent tin atoms. The ${ }^{119} \mathrm{Sn}$ CP-MAS spectrum of $\mathrm{Sn}_{2} \mathrm{Ph}_{6}$ in the solid state shows a singlet at $\delta=-142.1$.

There are very few examples of complexes containing bridging $\mathrm{SnPh}_{3}$ ligands. Bridging $\mathrm{SnPh}_{3}$ groups were found across the unsaturated $\mathrm{M}-\mathrm{M}$ bond of the dinuclear transition metal complexes $\left[\mathrm{M}_{2} \mathrm{Cp}_{2}\left(\mu-\mathrm{SnPh}_{3}\right)\left(\mu-\mathrm{PCy}_{2}\right)(\mathrm{CO})_{2}\right], \mathrm{M}=\mathrm{Mo}$ [22], $\mathrm{M}=\mathrm{W}$ [23]; across a $\mathrm{Ge}-\mathrm{Ge}$ edge of the complex polyhedral anion $\left[\mathrm{Ge}_{9}\left(\mu-\mathrm{SnPh}_{3}\right)\right]^{3-}[24]$; and across a $\mathrm{B}-\mathrm{B}$ edge of the polyhedral borane $\mathrm{B}_{5} \mathrm{H}_{8}\left(2,3-\mu-\mathrm{SnPh}_{3}\right)$ [25]. It is unusual to have a $\mathrm{SnPh}_{3}$ group bridging two metal atoms because the tin atom has only one unpaired valence electron. Clearly some sort of multicenter delocalized bonding can be anticipated for the Au_Sn bonding in the cluster of $\mathbf{6}$.

In order to understand the $\mathrm{Au}-\mathrm{Au}$ and $\mathrm{Au}-\mathrm{Sn}$ bonding in 6, geometry-optimized DFT molecular orbital calculations were performed. Selected molecular orbitals (MOs) that show the 
metal-metal orbital interactions in the $\mathrm{Au}_{2} \mathrm{Sn}_{2}$ ring are shown in Figure 2. The LUMO $(-2.21 \mathrm{eV})$ is a $\pi$-type MO delocalized across all four atoms. The HOMO $(-4.30 \mathrm{eV})$ is a delocalized four center - two electron $\sigma$-type orbital that shows the nature of the gold-tin bonding interactions, but it has a node along the $\mathrm{Au}-\mathrm{Au}$ vector. Because of this node, this orbital makes no significant contribution to direct bonding between the two gold atoms. The HOMO-1 $(-5.69 \mathrm{eV})$ is a symmetric two electron bond that is composed principally of d-orbitals from the Au atoms and with small contributions from atomic p-orbitals on the two Sn atoms. This orbital confirms the existence of a significant direct $\mathrm{Au}-\mathrm{Au} \sigma$-bonding interaction. By using conventional electron counting procedures, the $\mathrm{Au}-\mathrm{Sn}$ bonding in $\mathbf{6}$ would be best described schematically by the diagram $\mathbf{A}$ where the four dashed lines represent the four pairs of $\mathrm{Au}-\mathrm{Sn}$ interactions represented by the HOMO, formally $1 / 4$ of a bond for each $\mathrm{Au}-\mathrm{Sn}$ interaction, and the solid line between the two $\mathrm{Au}$ atoms is formally an $\mathrm{Au}-\mathrm{Au}$ single bond that is represented by the HOMO1.

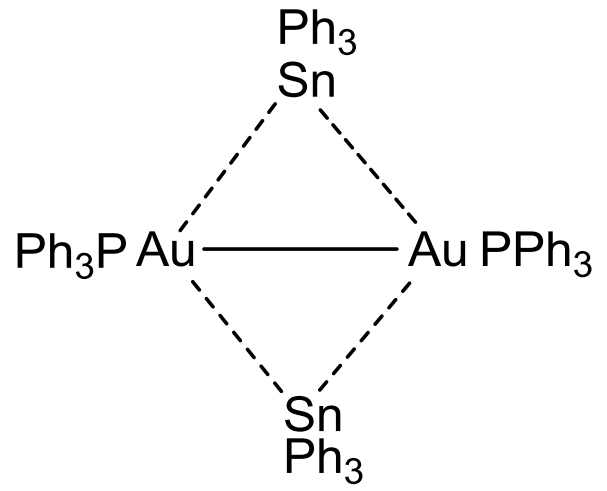

\section{A}

The complete DFT analysis also reveals three low-lying orbitals that show favorable overlaps that could be interpreted as supplementary metal - metal bonding. These are the HOMO-62, the HOMO-74 and HOMO-75. The HOMO-62 shows gold-tin bonding interactions and the HOMO74 and HOMO-75 both show $\pi$-overlaps derived from Au d-orbitals, see Figure 2, but because of 
their low energies they probably do not make major contributions to the total of the metal metal bonding.

Curiously, a number of years ago Schmidbaur reported the compound $\mathrm{Au}\left(\mathrm{PPh}_{3}\right)\left(\mathrm{GeCl}_{3}\right)$, 9 which was shown to be a dimer in the solid state and contained a significant, but long $\mathrm{Au}-\mathrm{Au}$ aurophilic interaction, 2.960(1) $\AA$, but the $\mathrm{GeCl}_{3}$ ligands are not of a bridging type [26].

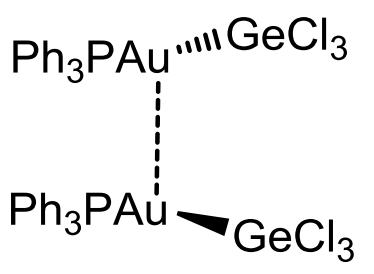

9

\section{Conclusions}

Compound 6 is a dimer of the formula unit " $\mathrm{Au}\left(\mathrm{PPh}_{3}\right)\left(\mathrm{SnPh}_{3}\right)$ ". The molecule is held together by a strong direct $\mathrm{Au}-\mathrm{Au} \sigma$-bonding interaction and two bridging $\mathrm{SnPh}_{3}$ ligands. The $\mathrm{Au}-\mathrm{Sn}$ bonding is best described by a four center - two electron bond having a node along the $\mathrm{Au}-\mathrm{Au}$ vector.

Acknowledgements. This research was supported by the following grants from the National Science Foundation: CHE-1111496 and CHE-1048629. Many thanks to Professor John Fackler for helpful discussions.

\section{References}

[1] (a) G. Li, R. Jin, Acc. Chem. Res. 46 (2013) 1749 - 1758. (b) M. Haruta, Gold Bull. 37 (2004) 27 - 36. (c) M. Haruta, Catal. Today 36 (1997) 153 - 166. (d) M. Haruta, M.; Date, Appl. Catal. A: Gen. 222 (2001) 427 - 437. (e) J. Oliver-Meseguer, J. R. Cabrero-Antonino, 
I. Dominquez, A. Leyva-Perea, A. Corma, Science, 338 (2012) 1452 - 1455. (f) A. S. K. Hashmi, G. J. Hutchings, Angew. Chem. Int. Ed. 45 (2006) 7896 - 7936. (g) C. Della Pina, E. Falletta, L. Prati, M. Rossi, Chem. Soc. Rev. 37 (2008) 2077 - 2095. (h) S. Lee, L. M. Molina, M. J. Lopez, J. A. Alonso, B. Hammer, B. Lee, S. Seifert, R. E. Winans, J. W. Elam, M. J. Pellin, S. Vajda, Angew. Chem. int. Ed. 48 (2009) 1467 - 1471. (i) A. A. Herzing, C. J. Kiely, A. F. Carley, P. Landon, G. J. Hutchings, Science 32 (2008) 1331 - 1335. (j) L. Zhang, Acc. Chem. Res. 47 (2014) $877-888$.

[2] (a) S. J. Freakley, Q. He, C. J. Kiely, G. J. Hutchings, Catal. Lett. 145 (2015) 71 - 79. (b) G. J. Hutchings, C. J. Kiely, Acc. Chem. Res. 46 (2013) 1759 - 1772. (b) G. J. Hutchings, Catalysis Today 238 (2014) 69-73. (c) Y. Zhang, X. Cui, F. Shi, Y. Deng, Chem. Rev. 112 (2012) 2467-2505. (d) G. J. Hutchings, Chem. Commun. (2008) 1148 - 1164. (e) J. A. Lopez-Sanchez, N. Dimitratos, N. Glanvilla, L. Kesavan, C. Hammond, J. K. Edwards, A. F. Carley, C. Kiely, G. J. Hutchings, Appl. Catal. A: Gen. 391 (2011) 400 - 406. (f) D. I. Enache, J. K. Edwards, P. Landon, B. Solsona-Espriu, A. F. Carley, A. A. Herzing, M. Watanabe, C. J. Kiely, D. W. Knight, G. J. Hutchings, Science 311 (2006) 362 - 365. (g) P. Miedziak, M. Sankar, M. Dimitratos, J. A. Lopez-Sanchez, A. F. Carley, D. W. Knight, S. H. Taylor, C. J. Kiely, G. J. Hutchings, Catal. Today 164 (2011) 315-319. (h) R. Wang, Z. Zhiwei Wu, C. Chen, Z. Zhangfeng Qin, H. Zhu, G. Wang, H. Wang, C. Wu, W. Dong, W. Fan, J. Wang, Chem. Commun., 49 (2013) 8250-8252. (i) L. Kesavan, R. Tiruvalam, M H. Ab Rahim, M. I. bin Saiman, D. I. Enache, R. L. Jenkins, N. Dimitratos, J. A. LopezSanchez, S. H. Taylor, D. W. Knight, C. J. Kiely, G. J. Hutchings, Science 331 (2011) 195199. 
[3] (a) J. M. Thomas, B. F. G. Johnson, R. Raja, G. Sankar, P. A. Midgley, Acc. Chem. Res. 36 (2003) 20. (b) A.B. Hungria, R. Raja, R. D. Adams, B. Captain, J. M. Thomas, P. A. Midgley, V. Golvenko, B. F. G. Johnson, Angew. Chem. int. Ed., 45 (2006) 4782-4785. (c) R. D. Adams, E. M. Boswell, B. Captain, A. B. Hungria, P. A. Midgley, R. Raja, J. M. Thomas, Angew. Chem. Int. Ed., 46 (2007) 8182-8185. (d) R. D. Adams, D. A. Blom, B. Captain, R. Raja, J. M. Thomas, E. Trufan, Langmuir, 2008, 24, 9223-9226. (e) R. D. Adams and E. Trufan, Phil. Trans Royal. Soc. 2010, 368, 1473-1493. (f) R. Burch, J. Catal. 71 (1981) 348-359. (g) R. Burch, L. C. Garla, J. Catal. 71 (1981) 360-372.

[4] Y. Maeda, T. Akita, M. Kohyama, Catal. Lett, 144 (2014) 2086-2090.

[5] (a) J. J. Hirner, Y. Shi, S. A. Blum, Accts. Chem. Res.44 (2011) 603 - 613. (b) M. Al-Amin, K. E. Roth; S. A. Blum, ACS Catal. 4 (2014) 622-629. (c) J. J. Hirner, K. E. Roth; Y. Shi; S. A. Blum, Organometallics 31 (2012) 6843-6850.

[6] W. Clegg, Acta Crystallogr., Sect.B: Struct. Crystallogr. Cryst. Chem, 34 (1978) 278 - 281.

[7] B. Findeis, M. Contel, L. H. Gade, M. Laguna, I. J. Gimeno, M. McPartlin, Inorg. Chem, 36 (1997) $2386-2390$.

[8] D. M. P. Mingos, H. R. Powell, T. L. Stolberg, Transition Met. Chem., 17 (1992) 334-337.

[9] D. Joosten, I. Weissinger, M. Kirchmann, C. Maichle Mossmer, F. M. Schappacher, R. Pottgen, and L. Wesemann, Organometallics, 26 (2007) 5696 - 5701.

[10] S. Hagen, I. Pantenburg, F. Weigend, C. Wickleder, L. Wesemann, Angew. Chem. Int. Ed., $42(2003) 1501-1505$.

[11] R. D. Adams, V. Rassolov, Y. O. Wong, Angew. Chem. Int. Ed. 53 (2014) 11006 - 11009.

[12] R. D. Adams, V. Rassolov, Q. Zhang, Organometallics, 32 (2013) 6368 - 6378. 
[13] D.V. Partyka, M. Zeller, A.D. Hunter, T.G. Gray, Angew. Chem. Int. Ed. 45 (2006) 81888191.

[14] SAINT+, version 6.2a, Bruker Analytical X-ray Systems, Inc., Madison, WI, 2001.

[15] G. M. Sheldrick, SHELXTL, version 6.1, Bruker Analytical X-ray Systems, Inc., Madison, WI, 1997.

[16] ADF2013; SCM Theoretical Chemistry, Vrije Universiteit, Amsterdam, The Netherlands, http://www.scm.com.

[17] J. P. Perdew, A. Ruzsinszky, G. I. Csonka, O. A. Vydrov, G. E. Scuseria, Phys. Rev. Lett. $100(2008) 136406$.

[18] D. M. P. Mingos, Pure Appl. Chem. 52 (1980) 705 - 712.

[19] H. G. Raubenheimer, H. Schmidbaur, Organometallics 31 (2012) 2507 - 2522.

[20] D. S. Weinberger, M. Melaimi, C. F. Moore, A. L. Rheingold, G. Frenking, P. Jerabek, G. Bertrand, Angew. Chem. Int. Ed. 52 (2013) 8964-8967.

[21] A. A. Mohamed, A. P. Mayer, H. E. Abdou, M. D. Irwin, L. M. Perez, J. P. Fackler, Jr., Inorg. Chem. 46 (2007) 11165-11172.

[22] (a) Alvarez, C. M.; M. A. Alvarez, M. E. Garcia, A. Ramos, M. A. Ruiz, M. Lanfranchi, A. Tiripicchio, Organometallics 24 (2005) 7 - 9. (b) M. A. Alvarez, M. E. Garcia, A. Ramos, M. A. Ruiz, Organometallics 25 (2006) 5374 - 5380.

[23] M. A. Alvarez, M. E. Garcia, D. Garcia-Vivo, M. A. Ruiz, M. F. Vega, Organometallics 29 (2010) 512-515.

[24] A. Ugrinov, S. C. Sevov, Chem. Eur. J. 10 (2004) 3727 - 3733.

[25] D. K. Srivastava, N. P. Rath, L. Barton, Organometallics 11 (1992) 2263-2273.

[26] A. Bauer; A. Schier; H. Schmidbaur, J. Chem. Soc., Dalton Trans. (1995) 2919 - 2920. 


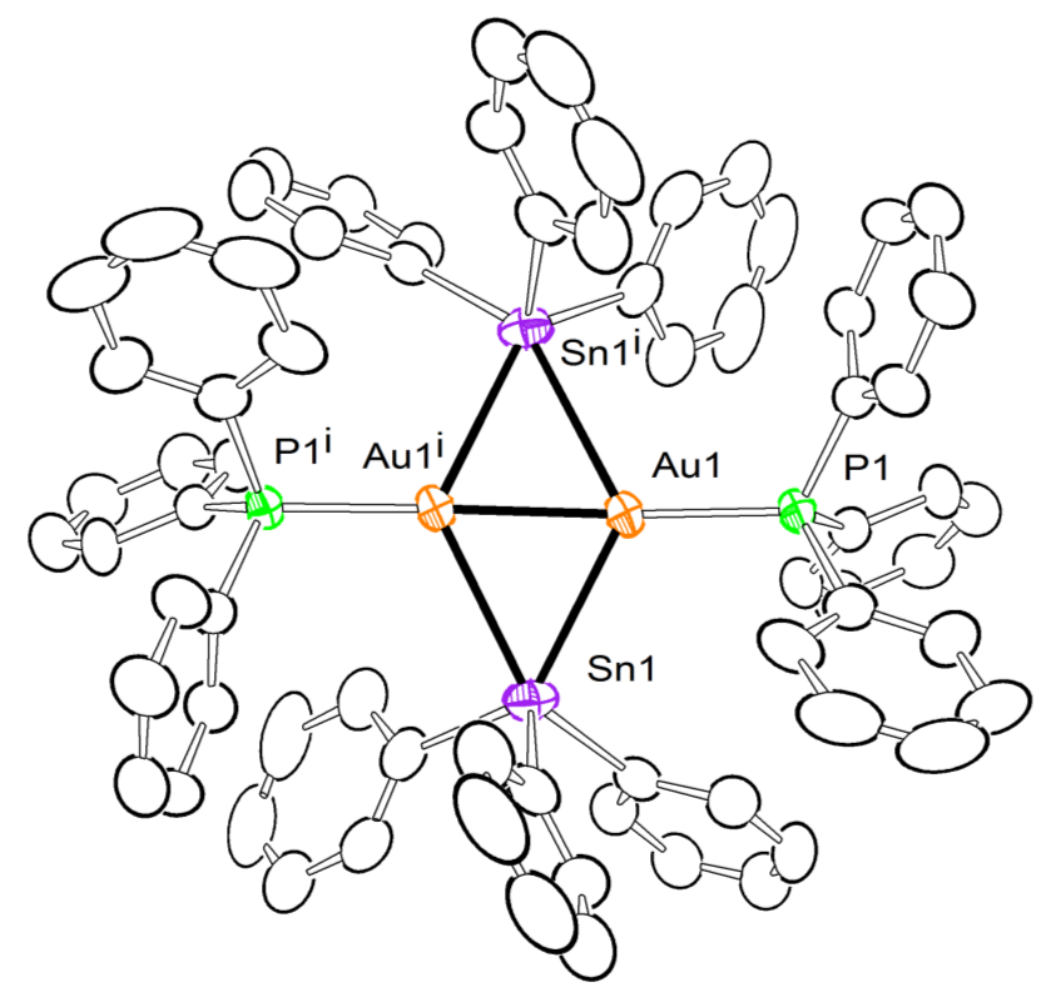

Figure 1. An ORTEP diagram of the molecular structure of $\left[\left(\mathrm{AuPPh}_{3}\right)\left(\mu-\mathrm{SnPh}_{3}\right)\right]_{2}, \mathbf{6}$, showing $30 \%$ thermal ellipsoid probability. 

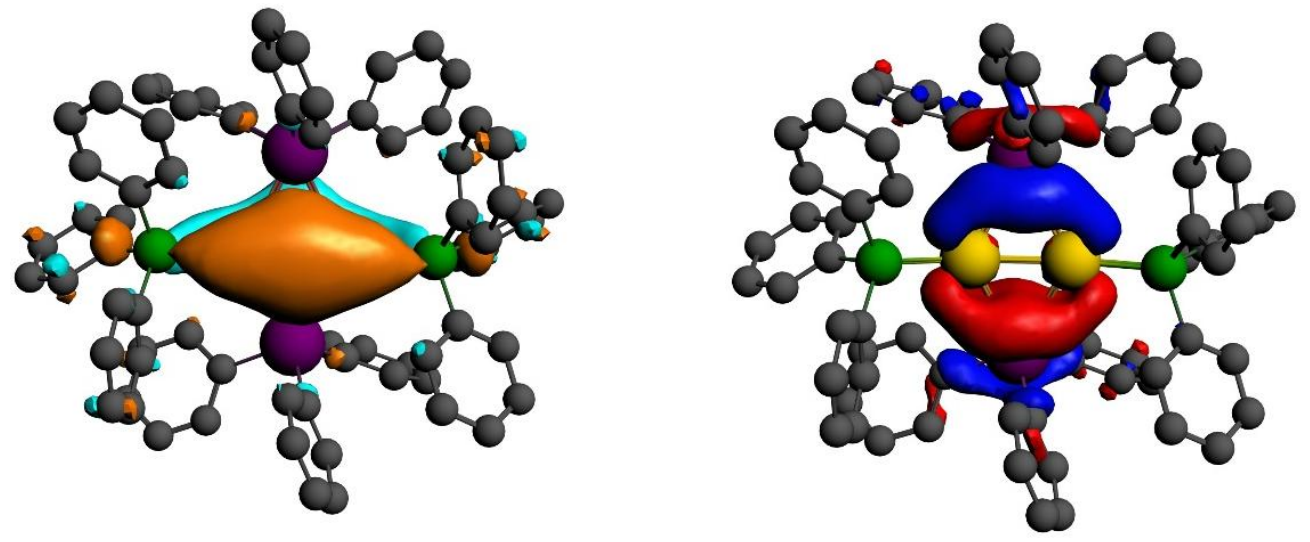

LUMO

$-2.20 \mathrm{eV}$

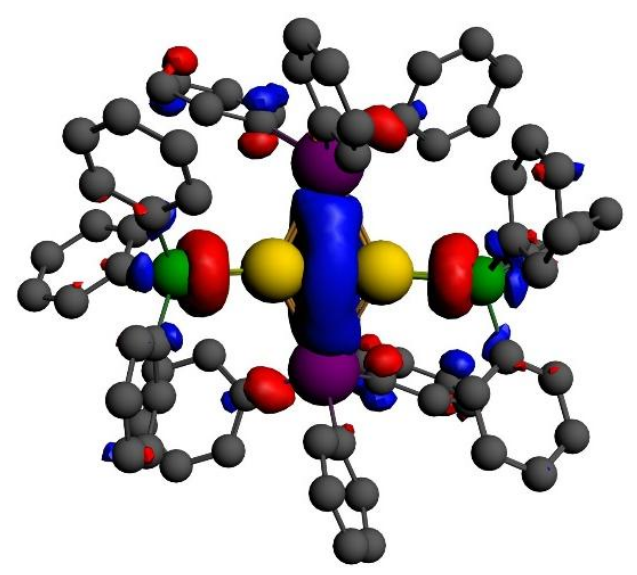

$\mathrm{HOMO}$

$-4.30 \mathrm{eV}$

HOMO-1

$-5.69 \mathrm{eV}$

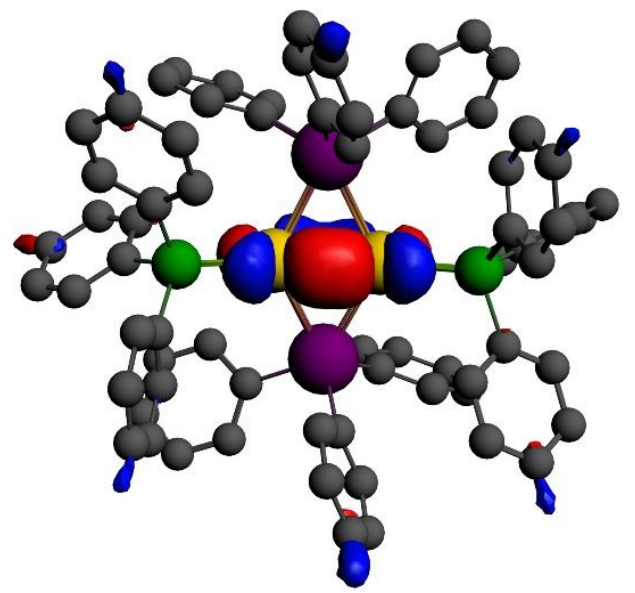

$\mathrm{HOMO}-74$

$-10.02 \mathrm{eV}$

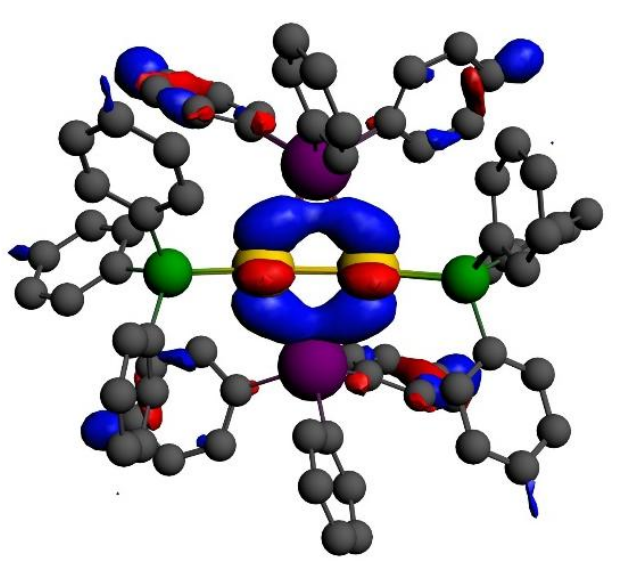

HOMO-62

$-9.49 \mathrm{eV}$

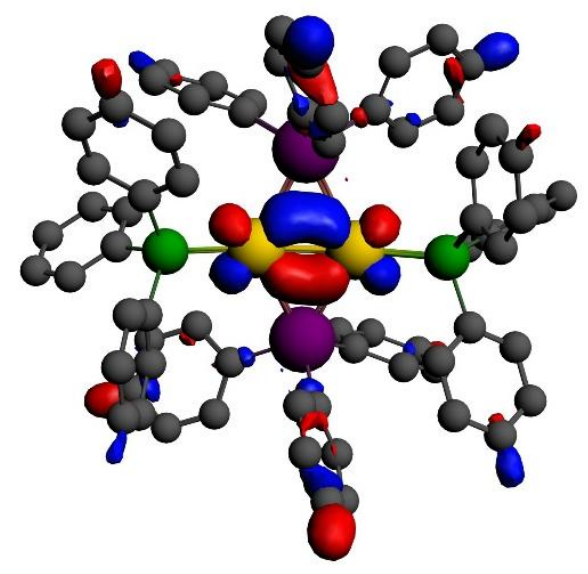

HOMO-75

$-10.13 \mathrm{eV}$

Figure 2. Selected Molecular Orbitals with calculated energies in electron volts $(\mathrm{eV})$ for the LUMO, HOMO, HOMO-1, HOMO-62, HOMO-74 and HOMO-75 of 6. 
Table 1. Crystallographic data for $\mathbf{6}$.

\begin{tabular}{|c|c|}
\hline Empirical formula & $\mathrm{Au}_{2} \mathrm{Sn}_{2} \mathrm{P}_{2} \mathrm{C}_{72} \mathrm{H}_{60} \cdot \mathrm{CH}_{2} \mathrm{Cl}_{2}$ \\
\hline Formula weight & 1618.54 \\
\hline Crystal system & Orthorhombic \\
\hline Lattice parameters & \\
\hline$a(\AA)$ & $14.2638(6)$ \\
\hline$b(\AA)$ & $22.9477(9)$ \\
\hline$c(\AA)$ & $9.8436(4)$ \\
\hline$\alpha(\mathrm{deg})$ & 90.00 \\
\hline$\beta(\operatorname{deg})$ & 90.00 \\
\hline$\gamma(\mathrm{deg})$ & 90.00 \\
\hline $\mathrm{V}\left(\AA^{3}\right)$ & $3222.0(2)$ \\
\hline Space group & $\mathrm{P} 2{ }_{1} 2{ }_{1}$ \\
\hline$Z$ value & 2 \\
\hline$\rho_{\text {calc }}\left(\mathrm{g} / \mathrm{cm}^{3}\right)$ & 1.71 \\
\hline$\mu(\mathrm{Mo} \mathrm{K} \alpha)\left(\mathrm{mm}^{-1}\right)$ & 5.437 \\
\hline Temperature $(\mathrm{K})$ & $294(2)$ \\
\hline $2 \theta_{\max }\left({ }^{\circ}\right)$ & 47.50 \\
\hline No. Obs. $(\mathrm{I}>2 \sigma(\mathrm{I}))$ & 7132 \\
\hline No. Parameters & 364 \\
\hline Goodness of fit $(\mathrm{GOF})^{\mathrm{a}}$ & 1.119 \\
\hline $\begin{array}{l}\text { Max. shift on final cycle } \\
\text { of refinement }\end{array}$ & 0.001 \\
\hline Residuals ${ }^{\mathrm{a}}: \mathrm{R} ; \mathrm{R}_{\mathrm{w}}$ & $0.0424 ; 0.1092$ \\
\hline $\begin{array}{l}\text { Absorption Correction, } \\
\text { Max/min }\end{array}$ & $\begin{array}{l}\text { Multi-Scan } \\
1.000 / 0.699\end{array}$ \\
\hline $\begin{array}{l}\text { Largest peak in Final Diff. Map }\left(\mathrm{e}^{-}\right. \\
\left./ \AA^{3}\right)\end{array}$ & 2.019 \\
\hline
\end{tabular}


Table 2. Selected intramolecular distances and angles for $\mathbf{6}$ from the X-ray structural analysis. ${ }^{a}$

\begin{tabular}{|c|c|c|c|c|c|c|}
\hline Atom & Atom & Distance $(\AA)$ & Atom & Atom & Atom & Angle $\left(^{\circ}\right)$ \\
\hline $\mathrm{Au} 1$ & Sn1 & $2.8207(6)$ & Au1 & Sn1 & Au $1^{\mathrm{i}}$ & $53.083(13)$ \\
\hline $\mathrm{Au} 1$ & $\mathrm{Sn} 1^{\mathrm{i}}$ & $2.9038(6)$ & Sn1 & $\mathrm{Au} 1$ & $\mathrm{Sn} 1^{\mathrm{i}}$ & $124.613(15)$ \\
\hline Au1 & $\mathrm{Au} 1^{\mathrm{i}}$ & $2.5590(5)$ & $\mathrm{P} 1$ & Au1 & $\mathrm{Au} 1^{\mathrm{i}}$ & $170.74(5)$ \\
\hline $\mathrm{Au} 1$ & P1 & $2.3336(17)$ & & & & \\
\hline Sn1 & $\mathrm{Sn} 1^{\mathrm{i}}$ & $5.069(1)$ & & & & \\
\hline
\end{tabular}

${ }^{a}$ Estimated standard deviations in the least significant figure are given in parentheses. $\mathrm{i}=$ symmetry related position

Table 3. Interatomic Distances for the DFT Geometry-Optimized structure of 6.

\begin{tabular}{|c|c|c|c|c|c|c|}
\hline Atom & Atom & Distance $(\AA)$ & Atom & Atom & Atom & Angle $\left(^{\circ}\right)$ \\
\hline Au1 & Sn1 & 2.806 & Au1 & Sn1 & Au1i & 53.7 \\
\hline Au1 & Sn1 ${ }^{\mathrm{i}}$ & 2.835 & Sn1 & Au1 & Sn1 ${ }^{\text {i }}$ & 124.1 \\
\hline Au1 & Au1 $^{\mathrm{i}}$ & 2.552 & & & & \\
\hline Au1 & P & 2.375 & & & & \\
\hline
\end{tabular}




\section{Graphical Abstract}
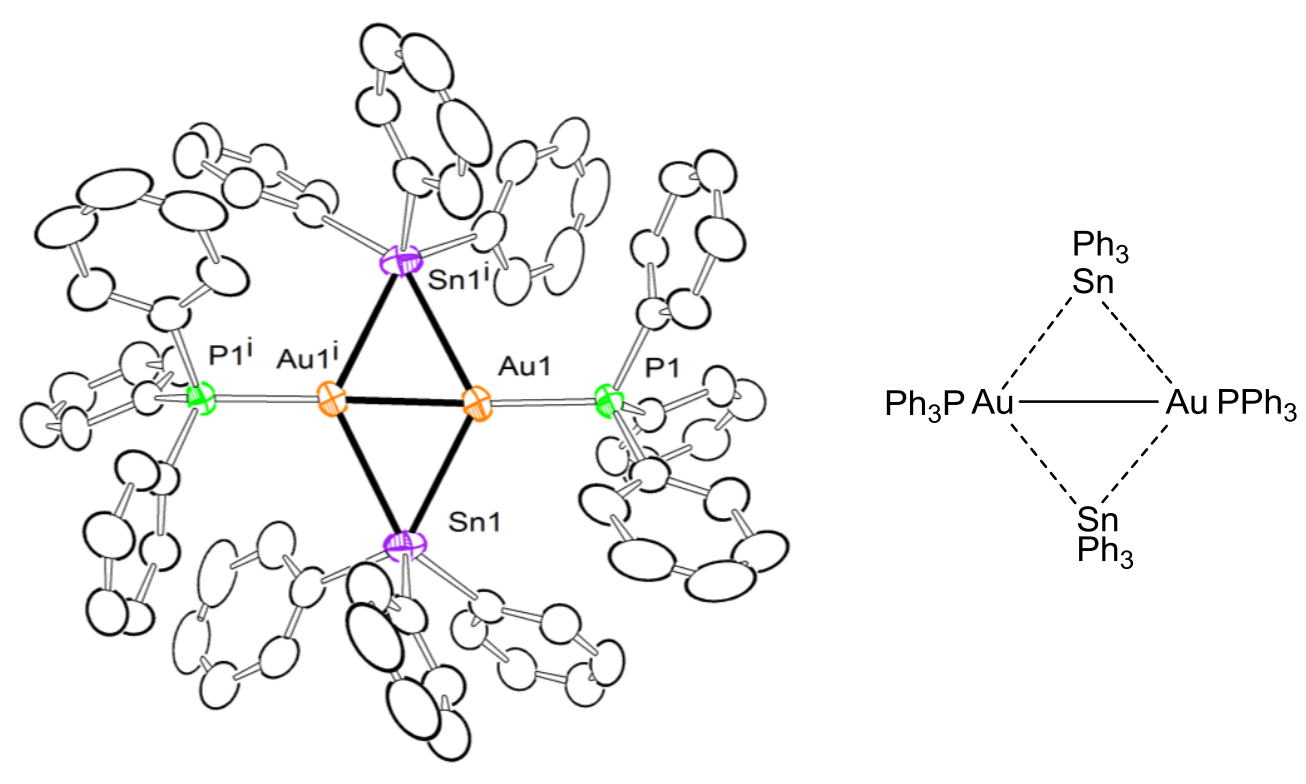